\title{
GO GREEN BEFORE YOU GO RED - POLICY IMPERATIVES FOR GREEN BANKING
}

\section{Dr. Archana Fulwari}

\begin{abstract}
:
Countries across the world are witnessing a heightened awareness in addressing the issues and challenges of sustainable development. There is no economic or social activity wherein the considerations of environmental viability may be seen as an option. The United Nations Sustainable Development Agenda 2030 has caught the collective imagination of leaders of the world pressing all stakeholders in the growth process to embrace the goals of Sustainable Development in all spheres of life. The historic Paris Agreement in 2015 gave further impetus to this phenomenon with sovereign countries pledging their nationally determined contributions to lower national emissions. In the achievement of these goals, the role of finance is extremely crucial. Particularly, countries have acceded to harmonize financial flows "with a pathway towards low greenhouse gas emissions and climate-resilient development" (UNFCC).

India too is making efforts to align its financial sector with the tenets of sustainability. The banking sector is one of the most important segments of the financial sector. In India, the banking sector has been increasing in size and coverage due to continual efforts of the government. It is of utmost importance therefore, that banks incorporate green practices in their operations. With this premise, this paper sought to review the state green banking in India. The paper also attempted to examine the green banking practices in other countries and draw important lessons from international experiences.
\end{abstract}

Keywords: Green Banking, Sustainable Development, Technology,

JEL Classification: G21, Q01, Q29

\section{Introduction}

Social and economic engagements of human beings have exerted great adverse impact on the environment as is evident in the climate changes that are being experienced across the globe. However, countries across the world have become aware of the urgent need to address this issue and to focus on increasing the efforts to mitigate the harmful effects of climate change. The United Nations Environmental Programme has therefore stressed on a growth trajectory that is sustainable and inclusive, both ecologically and socially. This orientation is well captured by the term 'green economy'. The tenets that underlie a green economy as well articulated in the 17 goals of sustainable development adopted by the world leaders as part of the United Nations Sustainable Development Agenda, 2030. The achievement of these goals 
requires trillions of dollar worth of investments. But the financial flows need to be harmonized "with a pathway towards low greenhouse gas emissions and climate-resilient development" (UNFCC).

Of the entire financial sector, banks comprise the most significant segment as they intermediate between the savers and borrowers for a wide array of routine operations. Banks play a significant role in the socio-economic development of the country. While banking operations do not directly exert negative impact on the environment, they indirectly generate environmentally harmful effects to a great extent through the activities of their clients, particularly, the industrial borrowers. Banks can play a significant role in encouraging and incentivising environment friendly operations by businesses. Moreover, banks have a great scope of embracing green practices by integrating technologies in their operations. They can also play an exemplary role in energy efficiency through adoption of the concept of green buildings. Adopting these measures enables banks to aid environmental protection and also to build reputation in the domestic and global economy, thereby earning greater dividends for itself through competitive advantage.

\section{Green Banking}

"Green Banking is an umbrella term referring to practices and guidelines that make banks sustainable in economic, environment, and social dimensions" (IDRBT, 2015). Green banking is also referred to as ethical banking or sustainable banking. The concept of green banking has three aspects. One is with reference to the banking practices with regard to its operations and management by incorporating the 3Rs, namely, Reduce, Reuse and Recycle, to achieve efficiency.

The second important dimension of green banking is their lending activities through which they can promote environment friendly investments through dedicated finance. Banks must include environmental performance of firms in analysing them rather than only financial performance. They may consider reallocation of credit to sectors with greater sustainability aspect. The third aspect of green banking is to put in place long term green banking policy at the national level that would address issues like appropriate fiscal and monetary incentives, appropriate financial structure for the economy and proper pricing of assets as per their environmental implications.

\section{Review of Literature}

Green banking is an emerging area of research. Most studies in India explore the green banking status of selected banks. Bhardwaj and Malhotra (2013), Ritu (2014), Shaumya and Arulrajah (2016), Kavitha and Rani (2016), and Jayadatta and Nitin (2017) have examined the green banking practices of various banks and the challenges and opportunities that green banking offer. Ritu (2014) observes that Indian banks lag behind their foreign counterparts in adopting green banking practices and suggests that the government and RBI must formulate guidelines for green banking and provide financial incentives to banks.

Nath, Nayak and Goel (2014) have highlighted the green rating standards set by the RBI and the reviewed the strategies adopted by public and private sector banks in India. Shaumya and Arulrajah (2017) have measured the impact of green banking practices on bank's 
environmental performance in Sri Lanka. Banks' environmental performance is measured in terms of reducing the use of paper and energy consumption and shift to non-conventional energy sources, green buildings as well as improvement in employee training and awareness about environment. Their study revealed that while employee-related, operations-related and policy-related green practices had positive impact on banks' environmental performance, the lacuna was with regard to customer-related green practices.

Sahu, Singh and Jain (2016) have studied the role of age factor in adopting green banking products and their findings suggests a positive bias among younger generations in the use of green banking services. Sharma, Sarika K, and Gopal (2014) have studied gender-wise level of awareness and satisfaction among bank employees with regard to green banking practices adopted by various banks. While gender was not found to be significant differentiating factor, there were mixed results with regard to different green banking products. Further, majority of the bank employees were unaware about the term 'green banking.'

The institute for Development and Research in Banking Technology (2013) discusses the green banking strategies and activities that banks could adopt. It also suggests setting up a green rating standard to rank banks according to their scores. Alexander (2016) has discussed the major aspects of banking policy of G20 countries that deal with institutional and market challenges encountered in the move to a more environmentally resilient economy.

Most studies on green banking in India are limited to examining the nature of green banking practices of banks in India. These studies basically cover two aspects of green banking, one, banks' lending to environment friendly sectors and, second, green practices in banking operations. Such studies examine the issue of green banking within a static framework wherein practices of banks are found to be piecemeal and lack coherence. There is absence of a clearly laid down road map on part of banks to tread the green path. This lacuna is in part the result of absence of futuristic, realistic and robust policy to bring sustainability at the core of all banking decisions and practices.

\section{Objectives}

Apropos the review of literature on the subject, the paper seeks to examine the green banking practices by Indian banks. More importantly, the paper aims at addressing the issue of green banking policy in India. Drawing from green banking practices across the countries, the paper seeks to impress upon the need for a definitive policy that gives a clear road map for banks to follow. For this purpose, the annual reports of various banks have been studied to trace the green banking practices adopted by them.

\section{Review of the Green Banking Practices of Banks in India}

Examining the annual reports of a large number of banks in India, several green measures are found to be practiced by banks. Based on the review of green banking practices adopted by various banks, three categories of green activities can be identified, namely,

- green operations

- energy conservation and use of non-conventional energy

- green financing.

Green operations involve the adoption of advanced technology in the routine transactions such as acceptance of deposits, fund transfer, line of credit, balance updates, etc. Internet 
banking, mobile banking and other means of electronic modes of effecting transactions go a long way in reducing the use of paper and thereby saving trees and environment. The second category of green practices relates to ways and means to economize on the use of electricity and water and exploit non conventional sources such as solar, wind and other natural sources of energy, as also water management, waste management, etc. The third classification of green practices entails bank lending to environment friendly sectors in particular. Beyond that it also implies that banks consider environmental performance of firms along with their financial performance in deciding their lending exposures. The following section enlists various activities and practices of banks as per the categories identified above.

\section{Technology based banking operations}

- Green-channel banking wherein all major transactions, such as withdrawals, deposits and remittances for small amounts are done paperless.

- Green Remit Card, which enables cash deposits to the beneficiary whose account number is mapped to the card.

- Encourage e-banking, mobile banking, e-wallets, and increase in PoS machines and ATMs.

- Digital supply chain finance solution for SMEs, digitized invoice discounting transaction on the 'Receivables Exchange of India Limited' (RXIL), and multiple digital modes of payments by customers to traders.

- Launching of digital banking such as payments, deposits, withdrawals, etc., in the rural areas achieving the twin objective of financial inclusion as well as inculcating paperless banking habits.

- Integration of retail internet banking facility with 'DigiLocker', a government of India initiative to create a digital repository of digital certificates and documents.

- Remittance of dividend and dispatch of documents and other communications in Electronic Form. Improvised email management solution for real time reporting and addressing of customer issues.

- Near-field Communication (NFC) based digital payment.

- Introduction of cash recyclers.

- Digital Financial Literacy and Awareness Programmes in 300 villages.

\section{Energy conservation and use of non-conventional energy}

- Initiation of projects to ascertain carbon footprints so that resource consumption pattern can be monitored and corrective action can be taken with the aim to reduce the power consumption by the IT initiatives.

- Recycling of dry waste offices papers and reused for making stationery.

- Recycling of sewage water and installation of water flow reducer.

- Use of wheat-straw based paper.

- Adoption of energy efficient measures such as solar ATMs.

- Installation of solar panels and windmills for in-house consumption of power.

- Green building offices and residential quarters incorporating elements like rainwater harvesting, adoption of environment friendly systems and technologies in the design such as energy efficient electrical and heating, ventilation, and air conditioning (HVAC), as well as environment friendly construction material and smart Building Management Software (BMS) and use of furniture made of recycled materials. 
- Pre-fabricated digital portable branches with self service machines for routing transactions set up in villages, in place of brick and mortar structures.

- Solar powered rural branches.

- Environmentally friendly disposal of e-waste through recyclers registered with pollution control board.

- Use of Organic Waste Composter to convert organic (kitchen) waste into manure.

- Tree plantation at premises and across the country.

\section{Green financing}

- Putting in place an environmental and social risk management framework for sustainable lending and procedures.

- Concessional loans to renewable energy projects, green home loans, organic farming, watershed management and rainwater harvesting to farmers.

- Financing the installation of solar street lights in villages, solar electrification of public health centres, and villages at large.

- Commitment to the government to finance viable renewable energy projects.

- Development of green bond framework in accordance to standards set by Climate Bonds Initiative to mobilise resources and earmark the proceeds for green projects like renewable energy, energy-efficient products and processes, waste management, pollution control, green transportation and so on.

- Issuance of Green Bonds.

- Financing Small and Medium Enterprises (SMEs) for the improvement of energy efficiency/conservation of energy and support SME projects in the area of green research and clean technology.

- Insistence on polluting manufacturing units to install water treatment plant and on obtaining clearances from central and state government pollution control boards before lending.

The review of green banking practices of banks reveals that there is a difference in the major focus areas between these banks. Some banks, particularly, the private sector banks are found to be pro-actively involved in integrating advanced technology to provide user friendly platforms to perform banking transactions. They are in a continuous process of upgrading next generation technology for enhanced customer convenience in using banking services. Although it appears that this strategy is oriented towards getting greater market share in the banking services sector rather than towards adopting green practices per se.

A few banks do have definitive action plan towards green banking such as a systematic policy of determining environmental and social risk for project financing and lending activities. Similarly, some banks have instituted the policy on environmental management that steers its efforts in energy efficiency, material resource efficiency, renewable energy use, and employee awareness. Such an approach paves the way for definitive action. At the other extreme are banks which lack any dedicated action plan to integrate green practices in their routine operations. Most activities of such banks are piecemeal CSR activities and lack conviction.

Conclusion and Recommendations: Green Banking Policy

Green banking policy is very important for any country to give a definite long term road map for banks to follow. The green banking practices followed by banks as of now are more piecemeal in nature. There are no specific guidelines set by RBI. At the most, the aspects of 
green banking are relegated to CSR activities of banks where social and environmental concerns are expected to be integrated in business operations. The Institute for Development and Research in Banking Technology, set up by RBI does not go beyond laying down suggestions on green banking strategies and activities that banks could follow. This betrays the attitude of treating green banking approach as an additional requirement on lines of priority sector lending rather than a norm by which banking must to be practised. The absence of clear and coherent policy on green banking is a great lacuna and needs to be addressed with conviction by the banking regulator. This is particularly important because in most developed countries, there is an increased stress on green financing. There are increasing cases of firms flouting environmental norms being closed down. Exporting firms are more closely scrutinized for their adherence to environment by foreign importers and investors. Failure to account for these developments would lead to increased credit risks for banks having exposure to such sectors, ultimately affecting their financial fundamentals. In order to avoid going red in the books of accounts, it is therefore, advisable that banks go green in their practices.

There is a need to mainstream green banking practices by framing robustly defined green finance and green banking standards. The major task is to find ways to address institutional hindrances and market challenges so that banks are facilitated in reallocating credit to environment friendly sectors. For this, direction may be sought from international practices. India can draw from the Equator Principles (EPs) proposed by International Finance Corporation, particularly for the banking sector. Incorporating these principles will lead to launching of novel financial products that are characterized by greater convergence between banking and environment preservation. Unfortunately, there is only a passing reference to the EPs by RBI when it advices banks to draw from it. There needs to be greater policy evolution and involvement to translate the EPs into well defined and measurable actions to walk the talk. Developed countries demonstrate that properly designed systems are very important to draw large amount of capital from private sources towards green financing. The following section highlights the institutional changes and policy initiatives that can be considered from practices across the world.

- Establish national development banks to play lead or concentrated role in green banking, particularly, long term lending to clean energy sectors. This approach is followed by Mexico and Turkey. China and India typically depend on their public sector banks to extend long term credit to clean energy projects. United Kingdom and the United States have set up green investment banks for mobilizing financing for renewable energy projects. The government of China gradually closed down inefficient coal mines and coalbased power plants due to environmental considerations. This determined action exposed banks to credit risk which ultimately resulted into banks becoming vigilant about environment risk before lending to such sectors. This exemplary action by China provides great insight into the kind of approach that may be adopted so as to induce banking practices in the desired direction. This also perhaps explains the high ranking of China in green bonds issuance, globally.

- Bring market reforms in terms of removal of fiscal distortions in the form of taxes and subsidies that encourage environmentally harmful activities. There is a need to align green banking policies with industrial policies so that the two builds synergy rather than being conflicting. Such an effort towards convergence of policies may create hiccups in the conventional practices but would soon facilitate markets to respond in line with environmental considerations, reinforced by insistence by various stakeholders in the link. 
- Subject banks to specific sustainability disclosure requirements with regard to environmental and social impact. This is of prime importance so that climate risk is correctly reflected and leads to appropriate resource allocation. This has been adopted by the European Union and stressed upon by the international Financial Stability Board. China and Brazil require their banks to include environmental sustainability in their risk management and governance.

- Once sustainability risks are well defined, there is a need put in place clear capital adequacy requirements to incorporate these risks. Brazil and China have officially integrated environmental risks and governance standards into prudential norms to be followed by banks. Brazil has in place a strong system of disincentives for private banks in the form of national legislation that imposes liability on banks for direct as well as indirect responsibility in the event of flouting of environmental regulations by their clients.

- Issue innovative financial products and structures to increase the scale and scope of mobilizing funds for green finance from savers and investors. European countries have focussed on securitization particularly for mobilizing greater investment for small and medium enterprises.

Indian financial sector can draw important lessons from the policy approaches adopted across the world. Each country may adopt the policy mix most appropriate to it. The need of the hour is to lay down explicit plans for mainstreaming green banking into the functioning of the banking system. There is a huge opportunity in integrating green banking practices and habits with the expansionary efforts of banks among the unbanked population. However, for this to be successful, multipronged approach would be required to address the issues like financial literacy, improved bandwidth, security and privacy.

\section{References:}

1. Alexander, K. (2016). 'Greening Banking Policy', G20 Green Finance Study Group (GFSG), unepinquiry.org/wpcontent/uploads/2016/09/10_Greening_Banking_Policy.pdf

2. Jayadatta, S. and Nitin, S. N. (2017). 'Opportunities, Challenges, Initiatives and Avenues for Green Banking In India', International Journal of Business and Management Invention, 6(2): 10-15.

3. Kavitha, N. V. and Rani, U. (2016). 'Green Banking - towards Sustainable Development', International Journal of Business and Management Invention, 5(2): 339-345

4. RauBhardwaj, B. and Malhotra, A. (2013). 'Green Banking Strategies: Sustainability through Corporate Entrepreneurship', Greener Journal of Business and Management Studies, 3(4): 180-193.

5. Nath, V. Nayak, N. and Goel, A. (2014). 'Green Banking Practices - A Review', International Journal of Research in Business Management, 2(4): 45-62

6. Ritu (2014). 'Green Banking: Opportunities and Challenges', 'International Journal of Informative \& Futuristic Research', 2(1). 
7. Sahoo, B. P., Mr. Singh, A. and Mr. Jain, N. (2016). 'Green Banking in India: Problems and Prospects', International Journal of Research - Granthaalaya, 4(8).

8. Sharma, N. Sarika, K. and Gopal, R. (2014). 'A study on customer's awareness on Green Banking initiatives in selected public and private sector banks with special reference to Mumbai', IOSR Journal of Economics and Finance, pp. 28-35, 7th International Business Research Conference. www.iosrjournals.org

9. Shaumya, K. and Arulrajah, A. A. (2016). 'Measuring Green Banking Practices: Evidence from Sri Lanka', International Journal of Innovative Research and Development, 5(2).

10. Shaumya, K. and Arulrajah, A. A. (2017). 'The Impact of Green Banking Practices on Bank's Environmental Performance: Evidence from Sri Lanka' Journal of Finance and Bank Management, 5(1): 77-90

11. Annual Report - 2016-17, SBI

12. Annual Report - 2016-17, Bank of Baroda

13. Annual Report - 2016-17, ICICI Bank

14. Annual Report - 2016-17, Axis Bank

15. Axis Bank Limited Business Responsibility Report 2016-17 https://www.axisbank.com/.../business-responsibility-reports/business-responsibility-re

16. Axis Bank Environment https://www.axisbank.com/docs/default-source/defaultdocument-library/9_environment.pdf?sfvrsn=0

17. Green Bond Framework - SBI https://www.sbi.co.in/portal/.../Green.../5bb248cb-13bb-459d-88d6-ef6abdabdb35

18. https://www.icicibank.com

19. Institute for Development and Research in Banking Technology (2013). 'Green Banking for Indian Banking Sector' http://www.idrbt.ac.in/assets/publications/Best\%20Practices/Green\%20Banking\%20Fra mework\%20(2013).pdf

20. UNEP (2015), 'Establishing China's Green Financial System', Inquiry: Design of a Sustainable Financial System, unepinquiry.org/wp.../China_Green_Finance_Progress

\section{Dr. Archana Fulwari \\ Assistant Professor, Department of Business Economics, Faculty of Commerce, The Maharaja Sayajiro University of Baroda, Lokmanya Tilak Road, Sayajigunj, Vadodara 390002, E-mail id.: archanafulwari@gmail.com Contact No. 9824523351}

